\title{
Revolution, Commemoration, Interpretation
}

The year 2017 saw a massive output of writing to mark the centenary of the October revolution. By conventional standards, this special issue of our journal is behind schedule. We might, however, cite various historians who agree on dating the decisive turning-point in the course of 1918. Seen in isolation, the "invisible insurrection" [Koenen 2017] in St. Petersburg hardly qualifies as a revolutionary event; it acquired that character through a sequel of violent, all-consuming struggle across the territory of the largest empire on earth. The week-long fighting in Moscow that followed the self-appointment of a Bolshevik government in the capital did not launch that process. But at the beginning of 1918, the dissolution of the Constituent Assembly set the course towards a one-party dictatorship, which had not been an obvious or generally expected outcome of the pronunciamiento in St. Petersburg. This was followed by the capitulation to Germany and its Austro-Hungarian ally (euphemistically labeled a "separate peace") and the establishment of a short-lived German empire in Eastern Europe. There were several aspects to this strategic shift. For the Bolsheviks who accepted the decision, and for Lenin in particular, it was a choice between priorities; they had to opt out of the European great power conflict and abandon all hopes of turning it into a revolutionary war, in order to take control of Russia. But it was also a gamble, and a double one. The possibility of a revolution that would knock Germany out of the war was not ruled out, although it was no longer invoked as a near-certain promise. But Lenin could not be unaware of the very different and more realistic scenario that American intervention, well underway at the time of the Brest-Litovsk capitulation, would quickly end the war on the western front. If that was indeed the decisive factor (as seems overwhelmingly likely), and if we agree that a stalemate on the western front would have been enough for Germany to win the war [Lieven 2016], we must conclude that American intervention saved the Bolshevik regime. It would not have survived for long as a satellite of a German empire in the east.

Two other aspects of the early 1918 crisis had major consequences for the course of events in that year. The disagreement over ending the war with Germany was not the first conflict within the Bolshevik party, but it was the one that came closest to a fatal split, and where Lenin's victory seems to have been mostly due to intimidation rather than persuasion. It left a traumatic legacy that in due course made it easier to enforce a ban on open debate. At the same time, the capitulation put an end to the coalition of Bolsheviks and Left Socialist-Revolutionaries; not that the Bolshevik leadership had ever intended to share the substance of power, but the Left SRs had tried to make their presence felt, and revolted against the acceptance of the German ultimatum. Their defeat and the accompanying repression deepened the estrangement between the Bolshevik regime and the socialist parties and became a prelude to their final suppression. But further developments towards 
the end of 1918 put the opponents of Bolshevism at a disadvantage. The civil war began in earnest, with White armies taking control of outlying territories and the Bolsheviks holding the center. Counter-revolutionary actions led by military cadres of the old regime could neither link up with working-class resistance in the cities nor with peasant revolts (the socialist parties were involved on both counts). This was not the least of the structural factors favoring the Bolsheviks.

In short, there are good reasons to stress the decisive role of events, internal and external, during the year 1918. From that point of view, the "ten days that shook the world" look rather like a leap into the void. It was the sequel, contingent and multicausal, that shaped the impact on Russia and the world. But 1917 can also be relativized on other grounds, and they are reflected in the thematic choices of this special issue. The protagonists of the seizure of power in St. Petersburg saw themselves as heirs, revivers, and consummators of a tradition. Their acknowledged ancestors were the radicals who had briefly taken center stage in the French revolution, as well as those who - much more marginally - defended radical causes in the revolution of 1848. Lenin had no qualms about admitting his affinities with the Jacobins, not least in response to his critics, but he also believed that he possessed a theoretical guide and a historical guarantee that would make his strategy more effective and lift it to a higher social level than that of the Jacobins. The Marxist teaching about class struggle and revolution was supposed to show the way.

Given this claim to represent more advanced forces and ideas, the record of imagining Russian events through French precedents is all the more remarkable. For historians and activists who have reasoned in terms of a revolutionary tradition, the connection between these two cases has always been a basic assumption. In 1917, references to French models antedated the Bolshevik push for power; there is no doubt that the ill-fated summer offensive of the Russian army was linked to visions of a Republican mobilization against external enemies, as in France during the 1790s. With the rise of the Bolsheviks, memories of French landmarks became more emphatic. The mythologized sequence begins with the "assault" on the Winter Palace, stylized to recall the storming of the Bastille, and the Congress of Soviets, presented with a fait accompli by the Bolsheviks but re-imagined as a more radical pendant to the assembly convened in 1789. The Jacobin experience was a key theme, but reactions to it and the outcome of its abortive turn were also invoked. On a more serious level, the looming threat of a "Thermidor," reversing the radical course, became a standard argument of intra-party opposition to the Stalinist dictatorship, and later helped Trotsky to defend his conceptually shaky view of Stalinism as a halfway house between revolution and restoration. On the other side, the specter of Bonapartism was used against Trotsky, but that analogy was also taken up by critics of full-blown Stalinism. The vastly influential interpretation of Stalin's regime developed by Isaac Deutscher may not unfairly be described as a mixture of Jacobin, Thermidorian and Bonapartist motives.

The assimilation of the two revolutions was not limited to political uses. A broad school of thought, known as the social interpretation of the French revolution, influenced by Marxism but far from reducible to that source, drew support from the analogy with Russia. The latter, case read as an example of social forces in the struggle for political power, lent added plausibility to such views on other major transformations. But the coupling of French and Russian experiences continued even when the interpretive focus shifted away from the social aspect. Comparative studies of revolutions, increasingly distanced from 
political concerns, were for obvious reasons inclined to foreground the "great revolutions," most revealing of historical patterns and underlying dynamics. The French and Russian revolutions are undisputed cases of that category; although the Chinese one is most often included, there are persistent problems with fitting it into the same framework. Its background and its roads to victory were very different from Western precedents; for one thing, it is much more difficult to distinguish a culminating phase form a longer process than in France or Russia (if the civil war is identified as such a phase, the pertinent objection is that it was, in fact, a struggle between two successor states to the Chinese empire, coming after the failure of Japanese conquest). A further problem is an unsettled outcome, not only during the twists and turns of Maoism but also in regard to the long-drawn-out re-adaptive process that began after 1976 .

Notwithstanding these obstacles, the Chinese case figures alongside the French and Russian ones in the most influential studies of great revolutions. Theda Skocpol [1979] still referred to social revolutions, and that may have obscured the revisionist thrust of her book, but as she argues, the radical social transformations intervene between a state crisis and a rebuilding of state structures on stronger foundations. Her reluctance to admit a significant role of ideology proved hard to justify, and the path was thus cleared for a more radical version of revisionism. In any case, the emphasis on state formation and state strengthening was primarily justified by reference to the Napoleonic and Soviet states that inherited the two paradigmatic revolutions. The shift was more far-reaching than the author realized at the time. Among other things, it raises the question of relations between revolution and empire.

The idea of radical revisionism, both in regard to the French revolution and on the subject of its affinities and contrasts with the Russian one, is more often associated with François Furet than with anybody else. At the end of the twentieth century, Furet influenced public opinion and debate in France to a degree rarely achieved by historians and was widely read in other countries. His revisionist project began with a book on the French revolution [Furet 1989a, first published 1978], focused on the interconnected roles of ideology and politics and hence strongly critical of the social interpretation. A later book [Furet 2000] proposed to settle accounts with the past illusion of Communism, not least by refuting once and for all its claim to the legacy of the French revolution. That book disappointed many readers [for a thoroughgoing critique, see Lefort 2007] and has not retained its instant reputation. But in between, Furet had published a seminal article on 1789-1917 as a "round trip" [Furet 1989b]. This text now seems more relevant to our purposes. Furet wrote it in connection with the bicentennial of the French revolution, and his aim was to show that in a fundamental sense, history had returned from a Russian road to nowhere to a French point of origin. The argument may be summed up in three main points.

Furet begins by noting the necessary but paradoxical connection between two aspects of the Communist appropriation of 1789 and its legacy. Soviet Communism proposed to re-enact and surpass the French model; both the continuity and the perfectibility of the revolutionary tradition were to be safeguarded. The two claims were mutually supportive and equally necessary for the maintenance of the regime and its international reach. The invoked ancestry of 1789 and its more radical sequel served to legitimize a power born of revolution and identified with a project of fundamental change, but permanently troubled by the discrepancy beween its original programme and the situation that it sought 
to master; the French connection also secured sympathies abroad, most obviously in the case of the strong French Communist party (to which Furet had once belonged, and with whose history he remained particularly concerned). The French Communists found it particularly easy to claim affinity with the radicals of the 1790s as well as those of 1917 . With the demise of Communism, complete in Eastern Europe and visibly imminent in the Soviet Union in 1989, this double genealogy collapsed, but with very different implications for the two models of reference. This is Furet's second point; he argues that whereas the Soviet model has vanished and left nothing to build on, the French one is entering a new afterlife: "The Revolution [the French one, J. P. A.] is more alive than ever through its democratic message, and dead, by contrast, as a privileged modality of change" [ibid.: 5]. The Soviet disaster has affected the general understanding of revolutions and discredited the attempts to idealize them.

Furet's portrayal of Communism as an aberration without legacy was well attuned to prevalent Western perceptions in the 1990s. The extraordinary U-turn that has taken place since then, and given rise to a revived Cold War discourse, shows that even the most sophisticated versions of this diagnosis got something seriously wrong. Now the emphasis of mainstream opinion is all on continuity between Soviet and post-Soviet Russia, with the most extreme offshoots describing Putin as a latter-day Stalin. A legacy is thus acknowledged, certainly seen as a malign one, but no less relevant for that. This is not the place to trace the continuities and discontinuities of modern and contemporary Russian history. But the return of the question throws new light on Furet's downsizing of the idea of revolution. It is certainly no longer defensible to think of revolutions as a privileged modality of change; the idea of a project of revolution as the epitome or culmination of modernity may be presumed dead. On the other hand, revolutions do represent a recurrent, complex and still imperfectly understood form of change; the loss of faith in revolutionary alternatives has not diminished the need for a comparative history of revolutions. As for the other aspect of the French heritage, the significance of 1789 and the sequel for the history of modern democracy is indisputable, but the relationship of democratic moments and currents to the overall dynamic of the revolutionary process is controversial, and so is the identification of democratic protagonists [for recent work with original variations on these themes, see Israel 2014].

The last consideration takes us to Furet's third point, only foreshadowed in the of the paper: "The end of a fictitious concatenation between the two events" leads to "a rediscovery of their singularity and at the same time their contingency" [ibid.: 16]. This is a lesson for historians, rather than for political thought, but it converges with the more sociological work of William Sewell on the "eventness" of the French Revolution in particular and revolutions in general. The contributions to the special section in this issue are written in that spirit, although none of the authors has a particularly close connection to Furet's work (some of them refer more directly to Sewell). They all emphasize the singularity of the French Revolution as an epoch-making event, with implications and consequences irreducible to any unfolding logic of a process or a project.

David Inglis surveys the vast and ramified history of thinking about the French Revolution, from Tocqueville and Marx to later generations of classical sociologists and the criticism of traditional views variously expressed by Arendt, Furet and Wallerstein. As Inglis shows, the"revisionist" argument most closely associated with Furet's name was 
not (as some of its advocates liked to think) a new and lasting paradigm for the study of events and experiences long seen through the distorting prisms of political ideologies and epochal self-images. Rather, it became the starting-point for an explosive and continuing broadening of horizons, including the problematization of boundaries between the modern and the premodern as well as the insertion of European upheavals in global history (in the context of the 1790s, the Haitian revolution is of particular importance). Eric Royal Lybeck takes off from the complicated and contradictory impact of the French Revolution on Germany. This is one of the fields arguably overshadowed by the exaggerated focus on Russian transformations of the French legacy. The interaction between France and the German political-cultural sphere was decisive for the nineteenth-century history of both countries, and thus for the destinies of Europe. Lybeck is particularly interested in the reflection of this highly conflictual encounter in new ways of thinking about history and society; the work of Friedrich Carl von Savigny is singled out for special attention. Putting the German responses to the French Revolution (and its imperial heir) into the history of sociology is not a matter of constructing a self-contained alternative to the conventional francocentric narrative, nor of resurrecting the notion of conserative origins of sociology; rather, it enriches a multilinear genealogy. Isaac Ariail Reed draws on new perspectives in cultural sociology, especially those related to performative language and its particular conflicts of interpretations. This view serves to foreground the question of sovereignty, central to all phases of the French Revolution but rarely given its due in state- or class-centred analyses. The problem is not simply the transfer of sovereignty through struggle, from kings to people and then to actors claiming to represent the latter; it also has to do with understanding and enacting the power to dominate and legitimate. Camil Francisc Roman adopts the viewpoint of political anthropology and uses it to clarify the question of religion and politics, their interaction in the French Revolution, and the significance of the outcome for modern politics. This is one of the issues that have come to the fore after the revisionist turn, e.g. in the writings of Gareth Stedman Jones, but Roman's approach differs from the hitherto most familiar ones. He places particular emphasis on the liminal situation created by the abolition of monarchy and the execution of the king, on the subsequent mutations of the sacred and their implications for the modern democratic imaginary.

This issue also contains texts more directly related to the Russian revolution. Nikolay Romanovskiy's paper discusses the progress and problems of historical sociology in post-Soviet Russia; the ups and downs of this discipline reflect broader concerns, not least the settling of accounts with the revolutionary past. The essay by Johann P. Arnason deals with problems of conceptualizing the Russian revolution, in the light of recent historical scholarship on this subject. Adam Coman's survey of the Israeli "critical historians" and their reevaluation of Zionism has a different focus; but the history of Zionism and its adversaries is not unconnected to modern revolutionary visions and experiences.

The special section on the French revolution was guest-edited by David Inglis and Eric Lybeck. The editors of the journal would like to thank them for their input and cooperation.

Finally, we publish reviews of a few recent publications, in part related to revolutionary themes. 


\section{Bibliography}

Furet, François [1981]. Interpreting the French Revolution. Cambridge: Cambridge University Press.

Furet, François [1989]. 1789-1917: aller et retour. Le Débat 57: 4-16.

Furet, François [2000] The Passing of an Illusion. The Idea of Communism in the Twentieth Century. Chicago: University of Chicago Press.

Israel, Jonathan [2015]. Revolutionary Ideas. An Intellectual History of the French Revolution from the Rights of Man to Robespierre. Princeton: Princeton University Press.

Koenen, Gerd [2017]. Die Farbe Rot. Ursprünge und Geschichte des Kommunismus. München: C. H. Beck. Lefort, Claude [2007]. Complications. Communism and the Dilemmas of Democracy. New York: Columbia University Press.

Lieven, Dominic [2016]. Towards the Flame. Empire, War and the End of Tsarist Russia. London: Penguin. Skocpol, Theda [1979]. States and Social Revolutions. A Comparative Analysis of Revolutions in France, Russia and China. Cambridge: Cambridge University Press. 